Educational Research for Social Change (ERSC)

Volume 8 No. 2, September 2019

pp. 1-13

ersc.nmmu.ac.za

ISSN: 2221-4070

\title{
Science Teacher Inquiry Identity: A Comparative Duoethnographic Study of Canada and Ethiopia Viewed Through a Bourdieusian Lens
}

\author{
Heather McPherson \\ Department of Integrated Studies in Education, McGill University \\ ORCID: 0000-0001-8783-4902 \\ heather.mcpherson@mail.mcgill.ca \\ Shanmugavalli Narayanan \\ Department of Integrated Studies in Education, McGill University \\ ORCID: 0000-0002-7739-7160 \\ shanmugavalli.narayanan@mail.mcgill.ca
}

\section{Abstract}

Globally, science teachers have been tasked with developing new pedagogies that incorporate inquiry-based and problem-based teaching strategies. In this article, we focus on a duoethnographic study of two teachers (the authors of the article). One of the authors teaches high school science in Canada, and the second has taught high school science in India and Ethiopia. We share our remarkably similar stories, which began with unaddressed pedagogical dilemmas and which, because of a lack in professional development opportunities, culminated in our return to graduate studies in science education. Drawing on the theoretical constructs of Bourdieu, we present our narratives as a study of how we negotiated the current science curriculum reform discourses that have shaped our professional identities. Our struggle to transform our professional identities has provided us with valuable insights as we work with preservice, novice, and in-service teachers to develop the reform-based pedagogies of inquiry-based and problem-based teaching.

Keywords: science education, reform, inquiry identity, duoethnography, Bourdieu

\section{Copyright: (c) 2019 McPherson and Narayanan}

This is an open access article distributed under the terms of the Creative Commons Attribution NonCommercial License, which permits unrestricted non-commercial use, distribution, and reproduction in any medium, provided the original author and source are credited.

Please reference as: McPherson, H. \& Narayanan, S. (2019). Science Teacher Inquiry Identity: A Comparative Duoethnographic Study of Canada and Ethiopia Viewed Through a Bourdieusian Lens. Educational Research for Social Change, 8(2), 1-13. http://dx.doi.org/10.17159/22214070/2019/v8i2a1 


\section{Introduction}

Identity has been described as being the stories told by persons (Sfard \& Prusak, 2005). In this article, we study the narratives of two high school science teachers who felt adrift in the current reform policy in science education. To develop a deeper understanding of how science reform policies have shaped the identity of in-service science teachers, we share the duoethnographic research of two graduate students, Heather McPherson and Shanmugavalli Narayanan (the authors of this paper). Heather, a science teacher of thirty years' experience, teaches in Québec, Canada. Shanmugavalli taught high school science in India for one year, and in Ethiopia for three years. We drew on a duoethnography methodology to chronicle our teaching narratives as we attempted to co-construct our science teacher identities. Together, we developed an understanding of how to position ourselves as science teachers with an inquiry identity as we collaborated, and reflected on our joint enterprise.

We envision an inquiry identity as the appropriation of content and pedagogical knowledge that is associated with inquiry-based (IB) and problem-based (PB) teaching (Deneroff, 2016). These pedagogies emphasise teacher-guided instruction in which students co-construct learning with the teacher and with other students (Chichekian, Savard, \& Shore, 2011). Co-construction of learning includes four processes: (1) engaging students in discourse to make connections between complex science ideas, (2) eliciting students' ideas, and adapting instruction to converge with student thinking, (3) helping students make sense of material by integrating laboratory work and theories with studentto-student discourse, and (4) pressing students for evidence-based explanations by asking students to co-construct explanations of a specific phenomenon (Bryce, Wilmes, \& Bellino, 2016; Windschitl, Thompson, Braaten, \& Stroupe, 2012). Enactment of these reform-based practices guided our praxis as we attempted to develop a new professional identity, and to redefine our roles as classroom teachers. Our parallel struggles played out in diverse cultural communities. However, our experiences with science education reforms were strikingly similar-characterised by frustration and a sense of isolation as our transitioning, but undeveloped, reform pedagogies seemed incongruent with the curriculum policies that we found compelling and well articulated.

Much has been written about the disconnect between science curriculum reform policies and classroom science pedagogy. This research study focuses on two science teachers who were engaged with science curriculum reform but were, nonetheless, unable to negotiate the opposing discourses of policy and practice. We (Heather and Shanmugavalli) first met in the autumn of 2017 when Shanmugavalli arrived in Canada to begin her doctorate. Working with the same supervisor, and sharing similar research interests in IB and PB pedagogy, we spoke at length about our frustrations and sense of isolation when we attempted to teach science using IB and PB learning in Canada and Ethiopia. In our discussions, it became abundantly clear that our science teacher trajectories were remarkably similar.

We have studied our experiences with science education reform as a duoethnography, a collaborative research methodology "in which two or more researchers of difference juxtapose their life histories," entering a dialogic conversation with one another to better understand self and the world (Norris, Sawyer, \& Lund, 2012). Our overarching research goal was to develop an understanding of how inservice science teachers struggle to enact an inquiry identity. We drew on the theoretical constructs of Bourdieu's social field theory to highlight the challenges we faced, and their eventual resolution as we strove to locate our inquiry identities and reconceptualise our ideas of what it means to be a science teacher.

Bourdieu's social field theory (1977) proposed that people are connected through complex social relationships that shift and give rise to new ways of knowing. Using Bourdieu's concept of habitus, teachers' practices have the potential to shift as they develop new understandings of IB and PB 
pedagogies. Teachers who are aware of curriculum reform, but are left to rely on traditional teaching strategies, can find themselves in a state of disequilibrium - trapped in a struggle between policy and practice. Bourdieu (1993) conceptualised field as the struggle among agents or institutions that transforms social practice. In our duoethnographic analysis, we studied our resistance to traditional teaching practices as we struggled to enact curriculum reform policies in Canada and Ethiopia; drawing on Bourdieu, the struggle to develop professional practice can shift the field. Therefore, professional identities change as teacher habitus or dispositions evolve - the field occupied by teachers is reshaped. Through engagement with critical reflection, study, and collaboration, we have reshaped our professional practice and reframed our identities, which are now informed by IB and PB pedagogies.

\section{Science Education Reform}

At the turn of the 21st century, the United Nations Educational, Scientific and Cultural Organization (UNESCO) and the Organisation for Economic Co-operation and Development (OECD) focused on how schools can adapt to expanding knowledge networks, technological advancement, globalisation, and new social and cultural environments (Ministry of Education, Québec, MEQ, 2007). Globally, educational organisations have undertaken the task of developing significant curriculum reforms. These curriculum reforms recognise that societies will be confronted with increasingly complex issues, therefore, young people must have the ability to integrate a vast amount of knowledge and transfer it to changing contexts (MEQ, 2007). It is essential that young people develop the capacity to identify and solve complex tasks and problems. Curriculum reforms have incorporated innovative teaching strategies that include IB and PB learning. These learning strategies encourage students to construct new knowledge by solving complex real-life problems and making connections between different disciplines (MEQ, 2007). Additionally, the incorporation of IB and PB teaching strategies increases student engagement and achievement (Aikenhead, 2004; Gengarelly \& Abrams, 2008; MEQ, 2007) because connections between societal challenges and science, technology, engineering, and mathematics (STEM) content are made explicit through promoting higher-order thinking skills (Ertmer, Schlosser, Clase, \& Adedokun, 2014).

\section{Professional development and curricular change}

As noted by the OECD, there is global acceptance that instruction needs to be more project based, and to provide students with educational experiences that challenge thinking across disciplines (Schleicher, 2018). Curriculum reforms were designed to connect theoretical knowledge with practical, real-life situations using a problem-solving approach (UNESCO, 2001). IB and PB teaching increase student engagement because the educational focus is on higher-order creative thinking, which provides students with opportunities to take ownership of their learning by asking questions that are scientifically relevant and based on evidence-to construct, evaluate, communicate, and justify explanations and possible alternative explanations (Luehmann, 2007). However, in-service teachers who began teaching before reform implementation are either unaware of IB and PB teaching or are not adequately supported to implement these practices in the classroom. Teachers' lack of experience thus "compromises their ability" to engage students in developing a deep and rich understanding of scientific concepts (Windschitl, Thompson, \& Braaten, 2008, p. 311).

In-service science teachers experience difficulties in incorporating IB and PB learning because enactment of these pedagogies depends on teachers' ability to shift their role from traditional transmitter of information to that of learning facilitator (Ertmer \& Simons, 2006). These pedagogies are complex and difficult to master and are therefore rare-even in the classrooms of experienced teachers, there is a focus on activity rather than on inquiry and higher-level thinking (Windschitl et al., 2012). In Australia, Melville (2010) noted that most educational reforms fail because they do not address the difficulties teachers face as they struggle to negotiate their pre-reform beliefs against 
reform ideals; furthermore, the area of reform causing the most difficulty for teachers is teaching science as inquiry.

Common themes that arise in the literature regarding teacher resistance to reform pedagogies in Canada include time constraints, teacher discomfort with creativity and innovation, the existence of traditional classroom structures, and reliance on tests (Nolan, 2011). Similarly, Ethiopian science classrooms remain primarily teacher-centred, with an emphasis on didactic instruction and with little active student learning, inquiry, metacognitive skill development, or opportunities for creativity (Joshi \& Verspoor, 2013). Teachers who lack training in high-quality practices such as IB and PB pedagogies resort to traditional forms of instruction, thereby failing to respond to students' thinking - a common obstacle to effective teaching in science classrooms (Windschitl, Thompson, \& Braaten, 2011). The development of these pedagogies requires support, time, and commitment on the part of teachers. Thus, there is an urgent need to retrain in-service teachers in effective pedagogic techniques that emphasise problem solving rather than recalling correct answers to simple problems (Hoot, Szente, \& Tadesse, 2007).

Research on reform discourse indicates that teachers find reform-based teaching challenging (Schneider, Krajcik, \& Blumenfeld, 2005). Yet, reform implementation depends on teachers' ability to enhance student learning through the development of high-quality teaching practices (Stoll et al., 2006). Stumbling blocks to reform implementation include a lack of training of in-service high school teachers (Gengarelly \& Abrams, 2008; Potvin \& Dionne, 2007; Thomson \& Gregory, 2013). Implementing educational reform depends on teachers' ability to access sustained professional development (Stoll, Bolam, McMahon, Wallace, \& Thomas, 2006). Meaningful professional development (PD) is of paramount importance if teachers are to develop innovative teaching skills and improve their professional knowledge (Thomson \& Gregory, 2013). One- or two-day workshops have not adequately prepared teachers to implement IB teaching in their daily activities. The absence of quality PD for in-service teachers has resulted in an implementation problem for curriculum reform (Ryder \& Banner, 2013).

\section{Methodology}

The research described in this article is informed by the methodology of duoethnography. Duoethnography builds on Pinar's (2010) method of currere, a theory of social reconstruction that draws upon four moments: regression, progression, analysis, and synthesis; by embracing these moments, we develop self-knowledge as we engage with the world. We drew on Norris, Sawyer, and Lund's (2012) tenets of duoethnography including: (1) a focus on one's life as a curriculum, as currere, (2) the data are polyvocal and dialogic - the dialogue and the identity of each speaker or writer are clearly stated, (3) the voices of both duoethnographers are made explicit, (4) the differences of the narratives are articulated and discussed, coexisting alongside one another, and (5) the meanings of the past are reconceptualised.

The data sources for this study included reflexive writings that we had engaged in during our doctoral studies. These reflexive writings captured our biographical lived experiences as we struggled with enacting science curriculum reforms. This is consistent with Pinar's first step of currere (Pinar \& Grumet, 2014). We employed thematic analysis (Braun \& Clarke, 2006) to code the reflexive writings. Emerging themes from the data were further developed as we discussed common patterns found in the writings. We then engaged in reflexive conversations to develop writing prompts for a second round of reflexive writing that was transactional and polyvocal. In the following section, we present our duoethnographic writings and conversations, which have been thematically organised. 


\section{Our duoethnography}

Heather: I completed my master's degree in plant breeding and plant genetics at a faculty of agriculture, which was perhaps a rare undertaking for a city girl. However, I was inspired by plant genetics, too lazy to learn animal biology as an undergraduate, and committed to research in applied science. My summer employment as an undergraduate was at Agriculture Canada, so the transition seemed natural. There were three in-between years where I worked in an animal physiology laboratory as a research assistant. After five years of scientific research, I fell in love with teaching, and enrolled in a bachelor of education programme.

Shanmugavalli: My passion for science learning began when I was in high school. I was motivated and encouraged to pursue biochemistry as an undergraduate. Having learned the fundamentals of biochemistry, and enjoying the topic, I was left wanting to learn more. Thus, I decided to pursue a master's degree in biochemistry. On finishing my master's, I chose to explore and to discover science through teaching. I taught high school for one year, and university for seven years, in southern India. However, I wanted to understand science teaching in the context of a different country. In 2011, I read a United Nations advertisement in an Indian newspaper, looking for university professors to work in a small university in northern Ethiopia. My application was successful, and I was appointed as an assistant professor in a biology department. At the end of my two-year contract, I moved to the capital and worked as a high school science teacher with an educational non-profit organisation. My responsibilities included teaching Grade 9 and 10 biology and chemistry. I found this teaching experience rich and rewarding. I collaborated with teachers from different parts of the world: an English teacher from Zimbabwe, an art teacher from the United States, an information technology teacher from England, and a mathematics teacher from Ghana.

Heather: Your time in Ethiopia sounds fascinating. Why did you leave your academic position in the north?

Shanmugavalli: I was challenged by living with a lack of necessities like water, electricity, and internet and was deliberately looking for a work opportunity to move from the small town to the capital. Heather, why did you leave your family and your life on the prairies?

Heather: When I tell my story of how I ended up in Québec, few believe it. Quite simply, I could not tolerate another winter on the Canadian prairies. The winters in Québec are balmy compared to the Canadian prairies. I have been teaching science at public high schools in Québec since the early 1990s.

In 2001, the Québec Education Program (QEP), referred to as the reform, was developed to meet two demands: to increase access to education and raise the graduation rate, and to provide high-quality education for all students. Four orientations were established as guidelines to achieve the stated objectives that served as a foundation for the QEP: success for all, the development of an educational programme with a focus on the development of competencies, integrated learning, and evaluation that promotes learning (MEQ, 2007). The overarching goal of the QEP is to ensure that all students have access to an education that enables them to reach their full potential as informed and empowered adults (MEQ, 2007). The QEP encourages teachers to incorporate a variety of pedagogical strategies including open-ended problems and experiments, research, and interdisciplinary projects that provide students with opportunities to acquire critical thinking skills (MEQ, 2007). Implementing these sophisticated reform-based pedagogies requires a paradigm shift for in-service teachers as they move from traditional to reformed teaching practices. The changing role of teachers is to guide or facilitate the instructional practices and instructional approaches through the incorporation of inquirybased teaching, and authentic problem-solving activities (Thomson \& Gregory, 2013). IB and PB 
teaching encourage teachers to utilise interrelated pedagogical practices that actively engage students in activities and conversations that promote student understanding of important science concepts and processes (Schneider et al., 2005).

Shanmugavalli: The challenges facing science education in Ethiopia include a lack of emphasis on critical thinking, problem-solving, and application of knowledge. Teachers tend to rely on traditional teaching methods based on rote learning and memorisation (Melesse, 2015). Moreover, a lack of relevance of school science to students' everyday life disengages them from science (Othman, Treagust, \& Chandrasegaran, 2008). Science teachers deliver lectures in science classrooms, and students memorise content from their textbooks and lecture notes to prepare for standardised examinations (Beyessa, 2014). Teachers are not able to adopt new approaches to teaching science because there are little to no continuing PD opportunities for them (Melesse, 2015). Additionally, limited teaching and learning resources, and the lack of professional support mechanisms, inhibit the potential for teacher growth and learning (Melesse, 2015).

Heather: In Québec, in-service science teachers were tasked with the enactment of complex new pedagogies, including IB and PB teaching and the development of competency evaluation (MEQ, 2007). The focus of science education shifted from traditional, teacher-centred delivery of content that relied on direct instruction dominated by teachers' actions including lecturing and student note taking, and hands-on laboratory activities with predetermined methods and outcomes (Thomson \& Gregory, 2013). When reform implementation was on the immediate horizon, I began to actively seek initiatives that focused on developing IB and PB teaching materials. I wrote numerous PB evaluation tools for laboratories and laboratory exams. Additionally, I was the school board (region) representative on a science coordinating committee that was consulted on the science curriculum reforms and had direct input during curriculum development. In 2008, when science reform implementation began at my high school, teachers were introduced to the science curriculum reforms during board-wide PD days. These one-day workshops focused on developing reform-based philosophies such as competency development and evaluation, teaching STEM, and using IB and PB learning as means of delivering content in the classroom. Also, there was a four-day workshop that provided teachers with an opportunity to learn the hands-on portion of the technological content of the new curriculum. When I look back, I realise that although I felt comfortable and inspired by the philosophy of the QEP, many of my colleagues did not share these feelings. During workshops, I observed that teachers experienced confusion, anxiety and, at times, anger. Nine years post implementation, some teacher and administrator conversations in my school include the hope that the reform will simply just "go away," or that "this too will pass." Overall, as an in-service teacher, I found that the PD opportunities offered were superficial and of short duration. The one-day workshops failed to adequately inform teachers of the rationale behind the reform. Open discussions on reform-related issues were rare-which is a noted impediment to teachers reaching a comprehensive understanding of the reform (MEQ, 2003). In my workplace, pervasive teacher discourses about the reform include resistance to the pedagogical practices outlined in reform policies. Some teachers I have spoken with feel that teaching through inquiry is only effective with enriched students, and that the use of PB learning confuses many students. Teachers observed that students have difficulty making sense of scientific content when the information is to be found in different sections of the textbook, and that students are confused when the presentation of scientific content is not strictly linear. Another concern expressed by my colleagues is that the very nature of the final exams-multiple choice questions and constructed short answer questions -is antithetical to IB and PB teaching. My interpretation, which is consistent with the literature, is that there is a lack of congruence between educational policies and the actual practices espoused by the educational system, considering the format of final exams (Thomson \& Gregory, 2013). I felt a sense of isolation as school. I was genuinely interested in IB and PB learning, but there was no support to do so. On multiple occasions, I was strongly encouraged to align my teaching practice with the teachers in my department in the name of solidarity. 
Shanmugavalli: As I progressed in my teaching, I revisited my basic science knowledge, allowing me to consider the challenges students encounter with understanding scientific concepts and applying them to solve problems. I was motivated to work closely with students to enhance their understanding of scientific models and concepts. I became interested in the knowledge that learners bring to the classroom, based on their experiences in their natural and social world. Thus, making science relevant to their daily lives became an important goal for me as a teacher. I participated in leadership workshops that focused on the importance of leadership qualities including prioritising organisation skills, fostering positive attitudes to learning, care for others, effective problem solving, and active listening attitudes in the teaching process. These skills helped me to increase students' engagement and interest in learning science. The challenges I faced while teaching high school students were also prevalent in my university science teaching. My university students lacked a conceptual understanding of basic biochemical concepts. My undergraduate and graduate students were faced with similar challenges in learning science. Many had difficulties in understanding and communicating scientific knowledge. In Ethiopia, I found it surprising that I had to deal with similar challenges. For example, students' lack of engagement with science was a significant issue in both contexts.

Most students were forced to rely on rote learning and memorisation of scientific facts in traditional learning environments. I noticed that other science teachers also had to deal with these issues in their classrooms. Unfortunately, we had limited PD opportunities. I believe that science teachers need to enhance their pedagogical skills to make science teaching more exciting and engaging for students. I felt professionally isolated, which was a source of frustration. After ten years of teaching, I began to view the issue of alternative pedagogies as a global challenge. My thirst for a solution to these challenges motivated me to pursue further studies in education. So, Heather, why did you decide to return to university and start a doctoral degree?

Heather: Why embark on a doctorate? My engagement with the Québec science reform left me with unanswered questions as I tried to make sense of the reform. I experienced tension between how I teach, and how I wanted to teach. I wanted to be better informed. I asked myself: "What is that IB learning?" I had frequently heard and read the term. "So, I am supposed to ask students questionsbut I do that already. What is the difference between what I do and what I should be doing? If IB teaching is a more effective way to teach students, how can I develop my craft?" I knew that I needed help. However, there was no one to talk to; there was no one to ask for clarification because these practices were new, and no one I worked with was enacting the practices in their classrooms. To date, there has been little PD in my school board that focuses on the development of inquiry-based teaching, nor on problem-based teaching.

My experiences with implementation of the science curriculum reforms have been fraught with an abundance of questions and few answers. Thus, I resolved to develop reform-based pedagogies through engagement in a doctoral programme focusing on science education. I am now developing the necessary skills to initiate PD opportunities for science teachers through professional learning communities (PLCs). Looking forward, I hope to share the knowledge I have gained with in-service and novice science teachers within a PLC. Additionally, I hope to work with preservice teachers to help them develop inquiry identities so they have the skill to enact IB and PB pedagogies when they begin their teaching careers.

Shanmugavalli: My professional progression as a science teacher is to integrate IB and PB teaching practices into all my classes. A significant portion of my doctoral coursework focused on the development of these skills. My doctoral research aims to work with preservice teachers to develop their IB and PB teaching practices for environmental sustainability. I hope preservice teachers will be 
better informed and therefore prepared to incorporate these practices in their pedagogy when they enter the teaching profession.

\section{Our Analysis Viewed Through a Bourdieusian Lens}

The duoethnographic methodology provided us with a useful tool for making meaning from our lived experiences with reform-based teaching. Together, we co-constructed and reconstructed our understanding of how to develop our inquiry science teacher identities. By juxtaposing our narratives, we realised differences and similarities in our educator journeys (which incorporates the fourth tenet of duoethnography). To guide our understanding of how in-service science teachers develop an inquiry identity, we drew on Pierre Bourdieu's social field theory (1977). Bourdieu's theory of practice is a suitable lens to analyse how teachers reconstruct their professional identities to include high-leverage teaching practices that are inquiry-based. Bourdieu's theory centred on the concept of habitus, which is explained as a "system of durable, transposable dispositions" (Bourdieu, 1977, p. 72). The habitus, or set of dispositions, provides a source of actions that are organised but lack a strategic intention. The dispositions of both Heather and Shanmugavalli inclined us to seek answers about reform-based teaching. Although we worked in disparate cultures, our solutions to navigating the frustrations of reform pedagogies were remarkably alike. Our journeys culminated in pursuing doctoral degrees in science education which, given our previous academic records of multiple degrees, is not surprising.

Bourdieu (1989) also explained habitus as a "system of schemes of production of practices and a system of perception and appreciation of practices." Our perception of IB and PB teaching strategies compelled us to refine our inquiry practices. Our habitus and dispositions-our core values-were open to the adoption of reform-based pedagogies, despite the lack of available expertise or adequate PD. Bourdieu explained the assumptions or core values of an agent as doxa: "a constructed view of the world that is so natural and self-evident that it is seen as the only view in existence" (Bourdieu, 1977, $\mathrm{p}$ 164). Doxa informed the decisions made by us two in-service teachers. However, our core values and the pervasive discourses in our professional communities left us feeling isolated and frustrated. In both Québec and Ethiopia, teachers resist or are uninformed about reform-based pedagogies (Joshi \& Verspoor, 2013; Potvin \& Dionne, 2007). Bourdieu (1991, p. 130) described the resistance of those who "have an interest in perpetuating a doxic relation to the social world which leads to the acceptance of established divisions as natural or to their symbolic denial.") He developed the idea that division and criticism are met by the "resistant force of orthodoxy" (Bourdieu, 1991, p. 131). Teachers resist change "through utterances, of making people see and believe, of confirming or transforming the vision of the world and, thereby, action on the world and thus the world itself" (Bourdieu, 1991, p. 170). Although we were ready for change, other teachers in our communities were either unprepared or insufficiently informed to transition their professional practice (MEQ, 2003).

We recognised the importance of IB and PB learning. However, we lacked the necessary training to implement these pedagogies in our daily practice. The result was a dissonance between our pre-reform teacher praxis and our development of reform-based pedagogies. This dissonance led to feelings of self-doubt, and a questioning of doxa. We were discouraged by our inability to transition from a traditional pre-reform habitus to that of IB and PB pedagogues. Exposure to the theories associated with IB and PB pedagogies led us to develop conflicting and multiple constructs of teaching. We found ourselves unable to incorporate the sophisticated reform-based pedagogies into our daily practice, and were left relying on traditional didactic forms of teaching. Bourdieu used the term orthodoxy to describe beliefs where multiple versions of reality are acknowledged, but only one version of reality is accepted. Orthodoxy is "a system of euphemisms, of acceptable ways of thinking and speaking the natural and social world" (Bourdieu, 1977, p. 169). Using Bourdieu's vocabulary, teachers may rely on traditional teaching strategies although they are aware of reform-based pedagogies. The discrepancy between teacher practices as outlined in curriculum reforms and safe traditional teacher practices 
placed us in a state of disequilibrium, resulting in an inner struggle. The struggle and subsequent imbalance between opposing positions is a necessary precondition to change doxa (Bourdieu, 1977). When doxa is questioned, generative change is possible.

We were faced with multiple road blocks as we worked to transition from traditional teaching to reform-based teaching. Learning the complex teaching strategies that are imbedded in IB teaching was impossible because there was no training or support. Furthermore, we were working with other teachers who were resistant to developing these pedagogies. Finding our voices, questioning our practice, and resisting the criticisms of colleagues was a struggle. Bourdieu explained that habitus and dispositions work within a field. A field is a structured space of positions in which an agent (or institution) engages in a struggle in which individuals seek to maintain or alter the distribution of power (Bourdieu, 2002). The notions of struggle and power relations are a fundamental component of a field. The structure of the field is determined by the agents aiming to transform it and is therefore mutable. We were engaged in both internal and professional struggles. Unable and unwilling to maintain the status quo, we were conflicted between pre-reform and reform-based pedagogies.

Our efforts to transform our professional practices altered the field as our habitus and dispositions were shifted through the development of new classroom pedagogies. Drawing on Bourdieu, the potential to change habitus arises when an agent questions her or his doxa (Bourdieu, 1977) or, as in our case, our constructed view of teaching practices. This shift of habitus was situated in the zone of struggle, or field. We found ourselves struggling in a state of disequilibrium as we realised that our professional practices were situated between relying on safe teacher practices and the mobilisation of new pedagogies. We were left questioning our identities. Using Bourdieusian theory, change in habitus is difficult because "the habitus tends to protect itself from crises and critical challenges by providing itself with a milieu to which it is as pre-adapted as possible" (Bourdieu, 1990, p. 61). However, we were eager to shift our habitus. Our decision to pursue graduate studies in science education, and to develop pedagogies consistent with curriculum reforms, speaks to our questioning of doxa, our struggles to learn and teach IB and PB. These efforts culminated in a change in habitus and transformation to our inquiry teacher identities.

Considering this analysis, we suggest that in-service teachers are more likely to develop reform-based pedagogies if they are aware of these innovative teaching practices. When teachers are aware of a change, professional tension between traditional and reform praxis is inevitable. In our case, this struggle led to a journey that culminated in a return to graduate studies that provided the necessary support to develop professionally and to reshape our identities as inquiry-based science teachers. The field shifted, effectively altered through a conversion brought about by pedagogic work that engendered a new habitus through "deculturating and reculturating techniques" (Bourdieu \& Passeron, 1990, p. 44). Based on our analysis, schools need to invest in PD activities that change mindsets-or habitus (Loucks-Horsley, Stiles, Mundry, Love, \& Hewson, 2009). The act of developing new pedagogies, of shifting identity from traditional to reform-based, can transform teacher habitus, ultimately leading to a new professional identity. Ways of thinking and teaching are potentially altered through engagement with PD.

We are now faced with a dilemma. Although we chose to return to university to develop our teacher identities, it is an unrealistic solution for most teachers. Exploring shifting habitus, and altering the field through a Bourdieusian lens, is useful to view the potential for reconceptualising in-service teachers' praxis. First, teachers must be aware of the innovative and sophisticated teaching strategies that are a vital component of all curriculum reforms. Second, and more critical, in-service teachers must have access to quality PD that goes beyond traditional one-day workshops-which have been an 
inadequate means of shifting teacher practices from traditional to high-quality (Potvin \& Dionne, 2007).

In our contribution to the reform discourse, we both seek to disrupt the field. Heather is currently developing and facilitating a PLC in her school board to provide in-service science teachers with an opportunity to establish IB and PB teaching strategies. As the habitus of in-service teachers is altered, the newly acquired skills will, we believe, become incorporated into their teaching repertoires through extensive pedagogic work that will encompass active participation in monthly meetings throughout one school year. Active engagement in a PLC has the potential to change habitus and reduce tensions and resistance associated with the development of an inquiry identity. We are both working with preservice teachers to provide supportive measures that will facilitate their adoption of IB and PB pedagogies. Preservice teachers resist reform-based pedagogies (Nolan, 2011; Thompson, Windschitl, \& Braaten, 2013) because their encounter with these practices is limited to the training provided in a faculty of education. During their schooling, from the ages of five to 18 years, preservice teachers engage with and observe in-service teachers for thousands of hours. These in-service teachers were trained before the reform policies that emphasise IB and PB teaching. We want to disrupt the cycle of social reproduction, to reverse the tendency for novice teachers to fall back on traditional teaching practices. Preservice teachers are informed by the notions of teaching and pedagogy that they observed as students in what Lortie $(2002$, p. 61$)$ refers to as the "apprenticeship of observation." The traditional, orthodox teacher habitus of preservice teachers can limit their ability to enact reformbased pedagogies, which therefore remain undeveloped. We are sharing our struggles to appropriate an inquiry identity for preservice teachers. Our hope is that preservice teachers will be better informed and therefore prepared to enact IB and PB practices when they enter the teaching profession.

\section{Conclusion}

Through the processes of sharing and learning with each other in a duoethnographic study, we engaged in critical reflection and examination of our professional practices. Drawing on Bourdieu's social field theory (1977), we have come to appreciate that teachers are connected through complex social relationships. In terms of Bourdieu's concept of habitus, our dispositions shifted as we cocreated new understandings of IB and PB pedagogies through a reflexive duoethnographic self-study. Our struggles brought about the development of our professional identities. Habitus is a useful theoretical tool for understanding and revealing the mechanisms of social reproduction and social change. For change to occur, teachers must question doxa and struggle to learn new ways of teaching. Teachers can transform the structure of the field when they struggle. In this study, the struggle was situated between the policy boundaries established by curriculum documents and praxis. To accomplish this shift, in-service teachers need opportunities to engage with quality PD. We were unable to access meaningful PD, and therefore struggled with reform pedagogies. Our sustained efforts to bridge the gap between policy and practice, to transform our professional identities, shifted the field.

Together, Bourdieu's framework and the method of duoethnography have informed this study of teacher identity construction. Engagement with reflection and collaboration enabled us to create new knowledge of our professional practice. As Bourdieu $(1989$, p. 23) explained, to alter a proposed concept, and to effect change, the vision must have a foundation based on reality, and there must be "objective affinities between the agents" who have been brought together. We were brought together through our duoethnographic collaboration and innate desire for change.

In conclusion, we argue that unless educational stakeholders address the difficulties faced by in-service and novice teachers to develop reform-based pedagogies, teachers will be unable to fully realise their capacity to enhance student learning by leveraging high-quality teaching practices. The importance of 
quality PD cannot be overstated. Without adequate supportive mechanisms to develop teachers' practice, the transition to high-leverage teaching will remain an uphill struggle. These challenges are as relevant today as they were 20 years ago when high-leverage teaching was first introduced. In particular, there is a dearth of research that explores these tensions in developing countries such as Ethiopia. Our reflexive study has helped us analyse and synthesise our position with IB and PB pedagogies. Through this dialogic research process, we have realised that our struggles are not, as we previously believed, unique to us individually. Rather, our efforts are part of an enterprise that has global significance, a reality that we came to understand through our polyvocal study.

\section{References}

Aikenhead, G. S. (2004). Science-based occupations and the science curriculum: Concepts of evidence. Wiley Online Library. Retrieved from https://onlinelibrary.wiley.com/doi/abs/10.1002/sce.20046

Beyessa, F. (2014). Major factors that affect Grade 10 students' academic achievement in science education at Ilu Ababora General Secondary of Oromia Regional State, Ethiopia. International Letters of Social and Humanistic Sciences, 32, 118-134. doi:10.18052/www.scipress.com/ILSHS.32.118

Bourdieu, P. (1977). Outline of a theory of practice (R. Nice, Trans.). Cambridge, UK: Cambridge University Press.

Bourdieu, P. (1989). Social space and symbolic power. Sociological Theory, 7(1), 14-25.

Bourdieu, P. (1990). The logic of practice. Stanford, USA: Stanford University Press.

Bourdieu, P. (1991). Language and symbolic power. Cambridge, USA: Harvard University Press.

Bourdieu, P. (1993). Sociology in question. London, UK: SAGE.

Bourdieu, P. (2002). Quelques proprietes des champs. Paris, France: Minuit.

Bourdieu, P., \& Passeron, J. C. (1990). Reproduction in education, society, and culture. London, UK: SAGE.

Braun, V., \& Clarke, V. (2006). Using thematic analysis in psychology. Qualitative Research in Psychology, 3(2), 77-101. doi:10.1191/1478088706qp063oa

Bryce, N., Wilmes, S., \& Bellino, M. (2016). Inquiry identity and science teacher professional development. Cultural Studies of Science Education, 11(2), 235-251. doi:10.1007/s11422-0159725-1

Chichekian, T., Savard, A., \& Shore, B. (2011). The languages of inquiry: An English-French lexicon of inquiry terminology in education. Learning Landscapes, 4(2), 93-109.

Deneroff, V. (2016). Professional development in person: Identity and the construction of teaching within a high school science department. Cultural Studies of Science Education, 11(2), 213-233. doi:10.1007/s11422-013-9546-z

Ertmer, P. A., Schlosser, S., Clase, K., \& Adedokun, O. (2014). The grand challenge: Helping teachers learn/teach cutting-edge science via a PBL approach. Interdisciplinary Journal of Problem-Based Learning, 8(1). doi:10.7771/1541-5015.1407

Ertmer, P. A., \& Simons, K. D. (2006). Jumping the PBL implementation hurdle: Supporting the efforts of K-12 teachers. Interdisciplinary Journal of Problem-Based Learning, 1(1). doi:10.7771/15415015.1005

Gengarelly, L. M., \& Abrams, E. D. (2008). Closing the gap: Inquiry in research and the secondary science classroom. Journal of Science Education and Technology, 18(1), 74-84. doi:10.1007/s10956-008-9134-2 
Hoot, J., Szente, J., \& Tadesse, S. (2007). Early childhood teacher education in Ethiopia: Progress and emerging challenges. Journal of Early Childhood Teacher Education, 27(2), 185-193. doi:10.1080/10901020600675158

Joshi, R. D., \& Verspoor, A. (2013). Secondary education in Ethiopia: Supporting growth and transformation. Washington, USA: World Bank.

Lortie, D. C. (2002). Schoolteacher (2nd ed.). Chicago, USA: University of Chicago Press.

Loucks-Horsley, S., Stiles, K. E., Mundry, S., Love, N., \& Hewson, P. W. (2009). Designing professional development for teachers of science and mathematics. Thousand Oaks, USA: Corwin Press.

Luehmann, A. L. (2007). Identity development as a lens to science teacher preparation. Science Education, 91(5), 822-839. doi:10.1002/sce.20209

Melesse, T. (2015). Differentiated instruction: Perceptions, practices and challenges of primary school teachers. Technology and Arts Research Journal, 4(3), 253-259. doi:10.4314/star.v4i3.37

Melville, W. (2010). Curriculum reform and a science department: A Bourdieuian analysis. International Journal of Science and Mathematics Education, 8, 971-991.

Ministry of Education, Québec (MEQ). (2003). Profile of the teacher as keystone in secondary reform implementation: Report to the Minister of Education. Retrieved from http://www.education.gouv.qc.ca/fileadmin/site web/documents/autres/organismes/CELA prof il-enseignants a.pdf

Ministry of Education, Québec (MEQ). (2007). Québec education program, Chapter 1: A curriculum for the 21st century. Retrieved from http://www.education.gouv.qc.ca/fileadmin/site web/documents/PFEQ/1 QEP Chap01.pdf

Nolan, K. (2011). Dispositions in the field: Viewing mathematics teacher education through the lens of Bourdieu's social field theory. Educational Studies in Mathematics, 80(1/2), 201-215. doi:10.1007/s10649-011-9355-9

Norris, J., Sawyer, R., \& Lund, D. E. (2012). Duoethnography: Dialogic methods for social, health, and educational research. Walnut Creek, USA: Left Coast Press.

Othman, J., Treagust, D. F., \& Chandrasegaran, A. L. (2008). An investigation into the relationship between students' conceptions of the particulate nature of matter and their understanding of chemical bonding. International Journal of Science Education, 30(11), 1531-1550. doi:10.1080/09500690701459897

Pinar, W. F. (2012). What is curriculum theory? New York, USA: Routledge.

Pinar, W. F., \& Grumet, M. R. (2014). Toward a poor curriculum. Kingston, USA: Educator's International Press.

Potvin, P., \& Dionne, E. (2007). Realities and challenges of educational reform in the province of Québec: Exploratory research on teaching science and technology. McGill Journal of Education, 42(3), 393-410.

Ryder, J., \& Banner, I. (2013). School teachers' experiences of science curriculum reform. International Journal of Science Education, 35(3), 490-514. doi:10.1080/09500693.2012.665195

Schleicher, A. (2018). World class: How to build a 21st-century school system. Paris, France: OECD Publishing. Retrieved from https://www.oecd-ilibrary.org/docserver/9789264300002en.pdf?expires=1535909783\&id=id\&accname=guest\&checksum=AFB1E9C554268DEBDB6B62620 3698EAC 
Schneider, R. M., Krajcik, J., \& Blumenfeld, P. (2005). Enacting reform-based science materials: The range of teacher enactments in reform classrooms. Journal of Research in Science Teaching, 42(3), 283-312. doi:10.1002/tea.20055

Sfard, A., \& Prusak, A. (2005). Telling identities: In search of an analytic tool for investigating learning as a culturally shaped activity. Educational Researcher, 34(4), 14-22.

Stoll, L., Bolam, R., McMahon, A., Wallace, M., \& Thomas, S. (2006). Professional learning communities: A review of the literature. Journal of Educational Change, 7(4), 221-258. doi:10.1007/s10833-0060001-8

Thompson, J., Windschitl, M., \& Braaten, M. (2013). Developing a theory of ambitious early-career teacher practice. American Educational Research Journal, 50(3), 574-615. doi:10.3102/0002831213476334

Thomson, M. M., \& Gregory, B. (2013). Elementary teachers' classroom practices and beliefs in relation to us science education reform: Reflections from within. International Journal of Science Education, 35(11), 1800-1823. doi:10.1080/09500693.2013.791956

UNESCO. (2001). The development of education: National report of Ethiopia. Ethiopian National Agency for UNESCO. Retrieved from http://www.ibe.unesco.org/fileadmin/user upload/archive/International/ICE/natrap/Ethiopia.pd $\underline{f}$

Windschitl, M., Thompson, J., \& Braaten, M. (2008). How novice science teachers appropriate epistemic discourses around model-based inquiry for use in classrooms. Cognition and Instruction, 26(3), 310-378. doi:10.1080/07370000802177193

Windschitl, M., Thompson, J., \& Braaten, M. (2011). Ambitious pedagogy by novice teachers: Who benefits from tool-supported collaborative inquiry into practice and why? Teachers College Record, 113(7), 1311-1360.

Windschitl, M., Thompson, J., Braaten, M., \& Stroupe, D. (2012). Proposing a core set of instructional practices and tools for teachers of science. Science Education, 96(5), 878-903. doi:10.1002/sce.21027 